\title{
PERANCANGAN COFFEE TABLE BOOK UNTUK MENDUKUNG PROGRAM PEMASARAN DESA WISATA TRANGSAN DENGAN IMPLEMENTASI 5W+1H
}

\author{
Nidyah Widyamurti ${ }^{1}$, Jauhari ${ }^{2}$, Hermansyah Muttaqin ${ }^{3}$ \\ Lalita Gilang ${ }^{4}$, Arif Ranu Wicaksono ${ }^{5}$ \\ 1,2,3 Prodi D3 Desain Komunikasi Visual, Sekolah Vokasi, Universitas Sebelas Maret \\ Jl. Kolonel Sutarto No.150K, Jebres, Surakarta 57126 \\ 4, 5 Prodi Desain Komunikasi Visual, Fakultas Seni Rupa dan Desain, Universitas Sebelas Maret \\ Jl. Ir. Sutami 36A, Kentingan, Surakarta 57126 \\ lalita.gilang@staff.uns.ac.id
}

Received: 16 Oktober 2020

Revised: 12 April 2021

Accepted: 28 April 2021

\begin{abstract}
Abstrak: Dalam konsep komunikasi pemasaran terintegrasi atau Integrated Marketing Communication (IMC), Desa Trangsan di Gatak, Kabupaten Sukoharjo, Jawa Tengah sudah mempunyai positioning sebagai desa wisata dengan produk olahan rotan sebagai produk unggulan. Desa Trangsan memiliki sistem kemasyarakatan yang baik. Ditunjukkan dengan adanya Unit Kecil Menengah (UKM) Klaster Rotan sebagai motor penggeraknya. Sebagai destinasi wisata, aktifitas UKM Klaster Rotan menjadi sajian atraksi wisata yang menarik, ditambah lagi dengan acara Grebeg Penjalin yang diselenggarakan setiap tahun. Desa Trangsan membutuhkan dukungan program komunikasi pemasaran secara terintegrasi untuk mempromosikan destinasi wisatanya agar menarik perhatian turis domestik dan mancanegara. Program komunikasi pemasaran Desa Trangsan ini selain bertujuan untuk meningkatkan perekonomian masyarakat, tapi juga dapat digunakan untuk mempersiapkan masyarakat desa untuk menghadapi persaingan global atas produk kerajinan rotan mereka. Penelitian dengan metode kualitatif dan menggunakan strategi deskriptif ini merupakan riset terapan sebagai pengembangan dari Tugas Akhir Prodi Diploma III Desain Komunikasi Visual UNS dan hasil penelitian lain sebelumnya. Penelitian dalam satu periode ini bertujuan untuk mendapatkan data kemudian memaparkan potensi sumber daya wisata Desa Trangsan dalam bentuk coffee table book dalam wujud cetak dan digital dengan kekuatan fotografi sebagai daya tariknya. Coffee table book ini akan digunakan sebagai media komunikasi dalam kegiatan pemasaran Desa Trangsan sebagai desa wisata dengan pemangku kepentingan.
\end{abstract}

Keyword: coffee table book, program komunikasi pemasaran, desa wisata

Abstract: Based on Integrated Marketing Communication (IMC) concepts, Trangsan Village in Gatak, Sukoharjo Regency, Central Java has a position as a tourism village with rattan products as their featured product. Trangsan Village has a good social system. This is shown by the existence of the Rattan Cluster Microenterprise as the advocate. As a tourist destination, the Rattan Cluster Microenterprise offers attractive tourist attractions along with the Grebeg 
Penjalin event that is held annually. Trangsan Village needs the support of an integrated marketing communication program to promote its tourist destinations in order to attract domestic and foreign tourists. This Trangsan Village marketing communication program is not only aimed at improving the community's economic matters but also be used to prepare village communities to face global competition for their rattan handicraft products. This research uses qualitative methods with descriptive strategies. This research is also applied research as a development of the Final Project from Diploma III Visual Communication Design department, UNS Study Program, and the results of another previous research. This research aims to obtain data and then describes the potential tourism resources of Trangsan Village in the form of a Coffee Table Book in print and digital form with the power of photography as its appeal. This Coffee Table Book will be used as a communication medium in the marketing activities of Trangsan Village as a Tourism Village.

Keyword: coffee table book, marketing communication program, tourism village

\section{PENDAHULUAN}

Desa Wisata Trangsan memiliki produk rotan yang sudah dikenal di pasar nasional maupun pasar ekspor (Apriyanto, 2016). Sebagai produsen kerajinan rotan terbesar kedua di Indonesia, kualitas kerajinan rotan Desa Trangsan tidak diragukan keunggulannya. Selain rotan, Pemerintah Kabupaten Sukoharjo dan masyarakat Desa Trangsan giat melakukan pembenahan lingkungan dengan mempercantik wajah desanya, membentuk Perkumpulan Untuk Peningkatan Usaha Kecil (PUPUK), membentuk Forum Rembug Klaster Rotan Trangsan, mendirikan Koperasi Serba Usaha (KSU) Trangsan Manunggal Jaya untuk meningkatkan keterampilan perajin, kualitas produk, dan pengelolaan produksi rotan, menggiatkan aktifitas Pokdarwis dan Bumdes untuk mendukung Desa Trangsan sebagai desa wisata. Penyelenggaraan event Grebeg Penjalin yang diselenggarakan tiap tahunnya membuat Desa Trangsan semakin menarik perhatian wisatawan. Kegiatan dan kultur sosial tersebut menjadikan masyarakat ikut berdaya dengan positioning Desa Trangsan sebagai desa wisata. Adanya sejumlah event pendukung kemajuan industri rotan tersebut mendukung ide penciptaan coffee table book.

Coffee table book adalah buku yang diletakkan di meja santai untuk minum kopi atau dapat juga ditemukan di ruang tamu duduk. Buku ini bisa menjadi inspirasi untuk 
membuka topik pembicaraan, digunakan sebagai hiburan, dan mengurangi rasa bosan. Secara ukuran, coffee table book cenderung besar dan berat, karena buku ini tidak menekankan pada fungsi ergonomi di mana kebanyakan buku mudah dibawa ke mana saja. Konten utama dalam coffee table book umumnya lebih berorientasi pada elemen visual seperti gambar dan foto (Wb., 2007). Mizan Publishing (www.mizan.com) mengategorikan coffee table book sebagai buku fotografi, yaitu buku yang tidak melulu dalam bentuk tulisan, namun berupa karya-karya foto seseorang atau beberapa orang yang dijadikan sebuah buku. Jenis foto yang sering digunakan dalam coffee table book adalah landscape photography, human interest dan documentary photography (Meidiyani, 2015).

Arida dan Pujani (2017) berpendapat, desa wisata merupakan salah satu bentuk penerapan pembangunan pariwisata berbasis masyarakat dan. Sedangkan Inskeep (1991) mengungkapkan, bahwa desa wisata merupakan bentuk pariwisata, di mana sekelompok kecil wisatawan tinggal di dalam atau di dekat kehidupan tradisional atau di desa-desa terpencil dan mempelajari kehidupan desa dan lingkungan setempat. Desa wisata, dapat memberikan banyak manfaat kepada upaya pengembangan berbagai sumber daya yang dimiliki oleh daerah pedesaan. Suatu desa wisata menyajikan atraksi sebagai daya tarik (alam, budaya, minat khusus), aksesibilitas, amenitas, dan lembaga pengelola (Marsono, 2019)

Berbagai potensi tersebut dapat menjadi daya tarik wisata yang dapat memberikan pengalaman autentik kepada wisatawan dan sekaligus memberikan kesempatan kepada masyarakat setempat untuk mendapatkan penghasilan tambahan melalui pariwisata. Promosi desa wisata dengan demikian dapat menjadi salah-satu upaya untuk menumbuhkan potensi kewirausahaan lokal, mendiversifikasi produk pariwisata, menopang perekonomian masyarakat setempat, serta merevitalisasi budaya lokal. Dalam hubungannya dengan pembangunan ekonomi wilayah, promosi sebuah desa wisata dapat mengatasi urbanisasi dan mendorong perekonomian pedesaan. Di samping itu pariwisata pedesaan berperan dalam meningkatkan kualitas hidup 
masyarakat pedesaan. Sebuah pembangunan lingkungan dapat dicapai melalui adanya desa wisata (Sunarta dan Arida, 2017).

Tujuan dari upaya promosi potensi desa wisata adalah untuk mempersiapkan warga yang tinggal di desa tersebut agar mampu menghadapi persaingan global (Arida dan Pujani, 2017). Dengan kata lain, upaya promosi melalui coffee table book bagi Desa Wisata Industri Kerajinan Rotan Trangsan ini bertujuan agar perajin rotan Trangsan mampu mempertahankan perekonomian dan budayanya. Penciptaan coffee table book sebagai media komunikasi kegiatan pemasaran produk rotan Desa Trangsan sebagai desa wisata merupakan salah satu upaya menggerakkan ekonomi masyarakat terkait dengan ilmu desain komunikasi visual, karena terdapat kaitan erat antara desain komunikasi visual dengan dinamika perekonomian. Implikasinya perekonomian yang memadai dapat membantu mempertahankan sekaligus mengembangkan warisan budaya.

Pemasaran merupakan suatu proses manajerial yang membuat individu atau kelompok mendapatkan apa yang mereka butuhkan dan inginkan dengan menciptakan, menawarkan dan mempertukarkan produk yang bernilai kepada pihak lain atau segala kegiatan yang menyangkut penyampaian produk atau jasa mulai dari produsen sampai konsumen (Shinta, 2011). Target dari pemasaran adalah menarik perhatian konsumen dengan produk dan harga yang menarik, menjual melalui channel penjualan secara menarik, dan mempromosikan produk dengan cara kreatif.

Konsep IMC menurut American Marketing Association (AMA) Dictionary adalah a concept that "recognize the added value of a comprehensive plan that evaluates the strategic roles of a variety of communication diciplines and that combines these disciplines to provide clarity, consistency, and maximum communication impact" (Juska, 2017). Program IMC fokus pada pendistribusian pesan brand secara ringkas, konsisten, dan jelas melalui berbagai media komunikasi. Pesan harus mendukung positioning produk, value proposition, dan strategi pemasaran suatu brand. Pendekatan IMC mempunyai 4 fungsi: inform (informatif), persuade (membujuk), entertain (menghibur), 
dan motivate (memotivasi). Dalam konsep komunikasi pemasaran terpadu (IMC), penetapan Desa Trangsan sebagai desa wisata dengan produk rotan sebagai produk unggulannya merupakan positioning tersendiri yang membuatnya unik di mata wisatawan. Akan tetapi, sebagai desa wisata, Desa Trangsan belum mempunyai media cetak atau digital untuk memaparkan semua potensi wisatanya kepada instansi pemerintah, kedutaan, dinas pariwisata, hotel, biro perjalanan wisata, dan sebagainya. Maka dari itu diperlukan sebuah coffee table book yang memuat profil, program yang dimiliki desa wisata, hingga keunikan karya kerajinan rotan dari Desa Wisata Trangsan ini.

Keunggulan dan daya tarik serta potensi Desa Trangsan sudah banyak menjadi bahan kajian, di antaranya dinamika ekspor kerajianan rotan di Desa Trangsan dalam periode tahun 1986-2009 (Apriyanto, 2016) ; analisis strategi pemasaran Desa Trangsan sebagai Desa Wisata Rotan (Mahanani, 2018); analisis pemberdayaan perajin melalui koperasi (Mursito dan Harini, 2017); dan kajian lain yang banyak mengulas pada aspek ekonomi dan pengelolaan perajin. Di sisi lain, perancangan coffee table book sudah dihasilkan oleh mahasiswa dari berbagai perguruan tinggi sebagai karya skripsi atau thesisnya. Andhika (2015); Meidiyani (2015); Kusuma (2016), Handojo, Karnadi, dan Renaningtyas (2017); Vincentius, Karnadi, dan Renaningtyas (2016); dan Gumilang dan Setiawan (2018) dalam kegiatan penelitiannya juga menghasilkan coffee table book untuk berbagai entitas. Akan tetapi, belum ada satupun karya coffee table book yang dihasilkan membahas tentang kerajinan rotan atau Desa Trangsan. Sementara itu, kajian-kajian seputar strategi pengembangan desa wisata, strategi pengelolaan destinasi wisata, pemberdayaan masyarakat menjadi kajian-kajian yang mendasari penelitian dan penyusunan coffee table book untuk Desa Trangsan ini.

Pelaksanaan riset dalam penelitian ini merupakan kegiatan yang mendasari penciptaan karya. Studi pendahuluan sudah dilakukan atas karya Tugas Akhir Mahasiswa Prodi DKV Sekolah Vokasi tahun 2019 dengan judul "Perancangan Coffee Table Book Sebagai Media Promosi Kerajinan Rotan Desa Wisata Rotan Trangsan Gatak Sukoharjo" 
karya Yusuf Andi Tri (Tri D., 2020) yang juga terlibat dalam penelitian ini sebagai anggota. Karya ini menarik untuk dikembangkan dengan program penelitian lanjutan yang akan menyempurnakan kedalaman bahasannya. Selain itu, penciptaan ini juga mendapatkan ide dari adanya event "Grebeg Penjalin". "Grebeg" (Jw) berarti perayaan rutin yang diadakan masyarakat Jawa untuk memperkenalkan suatu peristiwa penting. Sedangkan "Penjalin" (Jw) maknanya dalam Bahasa Indonesia adalah rotan.

Event Grebeg Penjalin yang sudah dimulai tahun 2016 menjadi ikon penting bagi Desa Trangsan. Penyelenggaraan event Grebeg Penjalin sebagai atraksi wisata Desa Trangsan yang dikelola oleh Tim Dosen ISI Surakarta sebagai penggagas Grebeg Penjalin telah memposisikan Grebeg Penjalin sebagai wujud keterbukaan warga Desa Trangsan untuk siap bersaing di pasar lokal dan nasional (Sumarno, Pramutomo, Cahyana, dan Dasmadi, 2019). Kajian inipun menjadi salah satu sumber referensi utama sebagai bahasan dalam coffee table book untuk Desa Trangsan.

Konsep yang mendasari penciptaan buku ini adalah konsep komunikasi pemasaran secara terpadu atau IMC. Strategi komunikasi pemasaran dengan konsep IMC ini sangat dibutuhkan untuk pengelolaan suatu brand. Perancangan coffee table book ini merupakan implementasi konsep strategi komunikasi pemasaran yang memuat informasi profil suatu entitas dengan berbagai keunggulan dan keunikannya dengan kekuatan fotografi sebagai kontennya. Coffee table book biasa digunakan sebagai cinderamata bagi instansi pemerintah untuk para pemangku kepentingan, atau sebagai media informasi dan promosi pariwisata di kedutaan, dinas pariwisata, hotel, atau biro perjalanan wisata.

Dari paparan yang telah disampaikan, selanjutnya dalam riset ini diajukan rumusan masalah sebagai berikut. (1) bagaimanakah konsep coffee table book beserta kekuatan fotografi yang dapat diciptakan sebagai media komunikasi kegiatan pemasaran produk rotan Desa Trangsan sebagai Desa Wisata? (2) bagaimanakah data pendukung untuk memaparkan potensi sumber daya wisata Desa Trangsan dalam bentuk coffee table book sebagai media komunikasi kegiatan pemasaran produk rotan 
Desa Trangsan sebagai Desa Wisata?

\section{METODE PENELITIAN}

Lokasi Penelitian ini adalah Desa Wisata Rotan Trangsan dengan alamat Dusun Luang, Gatak, Kabupaten Sukoharjo, Jawa Tengah. Penelitian dengan metode Deskriptif Kualitatif ini sejalan dengan pendapat Subandi (2011), bahwa dalam penelitian kualitatif, karakteristik utama berasal dari latar belakang alami/ kenyataan di masyarakat, menggunakan metode kualitatif dengan langkah pengamatan, wawancara, dan penelaahan dokumen dengan tujuan untuk mendeskripsikan, menggambarkan secara sistematis, faktual, dan akurat mengenai fakta-fakta, sifat, serta hubungan antar fenomena yang diselidiki dengan cara menggambarkan situasi atau kejadian, tetapi juga menerangkan hubungan, membuat prediksi serta mendapatkan arti dan implikasi dari suatu masalah yang ingin dipecahkan.

Pengumpulan data menggunakan instrumen wawancara, observasi, FGD, dan pemotretan. Wawancara dilakukan kepada Kepala Desa, Forum Rembug Rotan Trangsan, Koperasi Serba Usaha (KSU) Manunggal Jaya, Pokdarwis, dan Bumdes di Desa Trangsan. Observasi dilakukan dengan cara mengunjungi lokasi, berinteraksi dengan obyek penelitian, dan melakukan pengamatan atas fenomena yang terjadi. Focus Group Discussion $(F G D)$ dilakukan untuk menyamakan visi, mendiskusikan konten buku, mendiskusikan teknis pelaksanaan kegiatan, dan menjalin kedekatan dengan seluruh elemen masyarakat Desa Trangsan. FGD ini dihadiri oleh 20 peserta yang terdiri dari anggota peneliti, Forum Rembug Rotan Trangsan, Koperasi Serba Usaha (KSU) Manunggal Jaya, Pokdarwis, dan Bumdes di Desa Trangsan, pengusaha kerajinan rotan, dan pengelola program Desa Wisata yang menghasilkan kesepakatan atas judul dan konsep coffee table book yang akan disusun, teknis pelaksanaan penyusunan, sistem koordinasi, jenis materi dan teknis pengadaannya.

Data dijaga keabsahannya menggunakan triangulasi metode. Dengan prosedur mencocokkan data berasal dari wawancara, observasi, dan dari FGD (Tracy, 2013). 
Setelah ketiga sumber cocok, maka dinyatakan valid. Analisis menggunakan "teknik analisis interaktif" (Tracy, 2013). Dengan prosedur (1) pengumpulan data; (2) reduksi data; (3) paparan data; dan (4) penyimpulan.

Pemotretan dilakukan pada beberapa point penting sesuai dengan konsep buku dengan data dan sumber referensi dari data/arsip, artikel, jurnal, buku, laporan hasil penelitian terdahulu, file blog maupun web terkait pada berbagai kajian yang relevan.

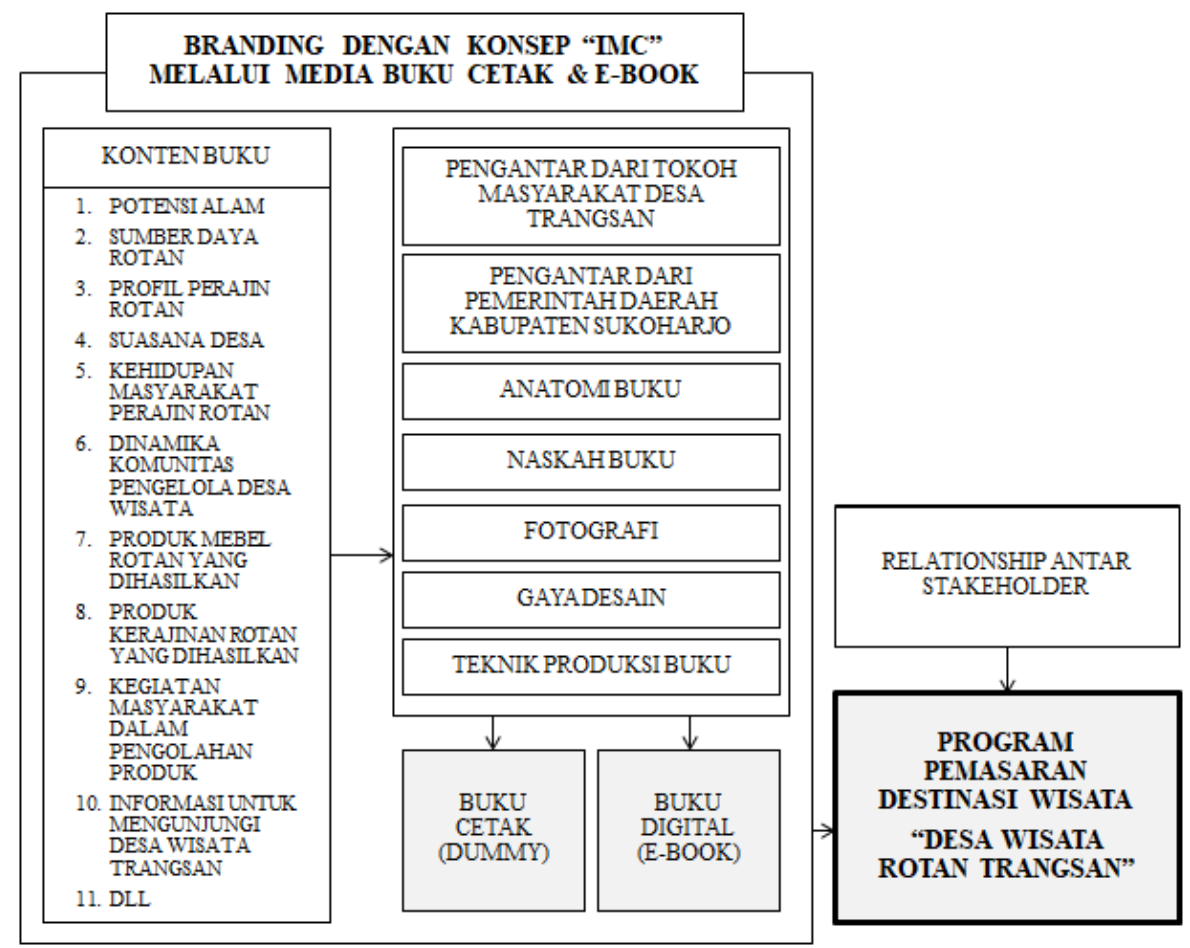

Gambar 1. Alur Proses Pelaksanaan Kegiatan Peneliti

Sebagaimana alur proses pelaksanaan kegiatan penelitian pada Gambar 1, kerangka pemikiran kegiatan penelitian diawali dengan pemahaman atas konsep IMC dan penerapannya pada karya buku cetak maupun e-book, sehingga penyusunan isi coffee table book mampu menampilkan konsep desa wisata yang menampilkan Desa Trangsan, produk rotan, figur dan aktivitas masyarakat Desa Trangsan sebagai sebuah destinasi wisata yang sekaligus berperan penting sebagai obyek destinasi wisata. Luaran berupa coffee table book dalam versi cetak dan e-book ini akan berperan sebagai media komunikasi yang akan berperan strategis sebagai media pemasaran dan hubungan Desa Trangsan dengan para pemangku kepentingan. 


\section{HASIL DAN DISKUSI}

\section{Konsep Coffee Table Book sebagai Media Komunikasi Pemasaran Produk Rotan Desa} Wisata Industri Kerajinan Rotan Trangsan

Coffee table book Desa Trangsan ini merupakan buku yang didominasi foto-foto profil Desa Trangsan sebagai Desa Wisata Industri Kerajinan Rotan yang dilengkapi dengan sedikit narasi (teks) dan caption yang berfungsi sebagai media informasi dan media promosi kepada pemangku kepentingan. Konsep visual yang digunakan adalah visual driven dengan desain layout minimalis. Halaman-halaman buku didominasi foto dan dilengkapi dengan caption dan sedikit narasi/pengantar pada awal subbab dengan perbandingan 3:1. Coffee table book ini berukuran $21 \times 26 \mathrm{~cm}$ dan akan diproduksi dalam format $E-B o o k$.

Karya fotografi dibuat dengan konsep: 1) Landscape Photography yang menggambarkan suasana Desa Trangsan sebagai Desa Industri Kerajinan Rotan dari berbagai sudut, 2) Architectural Photography yang terdiri dari foto-foto bangunan rumah produksi (pabrik); rumah penduduk sebagai workshop para perajin; showroom kerajinan rotan karya perajin; dan gudang bahan baku, 3) Still Life Photography yang menampilkan stok bahan baku mentah; stok bahan baku yang sudah diolah/siap produksi; gambar desain, rekaman praproduksi; beragam produk kerajinan rotan yang dihasilkan (belum finishing); beragam produk kerajinan rotan yang dihasilkan (setelah dilakukan finishing); dan beragam sarana prasarana produksi yang digunakan oleh perajin, 4) Photo journalism yang menceritakan aktifitas/kehidupan sehari-hari masyarakat Desa Trangsan sebagai perajin; suasana event pameran nasional/internasional yang pernah pernah diikuti; suasana event grebeg penjalin; suasana kunjungan pemangku kepentingan dalam beragam kegiatan seperti transaksi perdagangan; suasana kunjungan wisatawan dalam menikmati wisata edukasi; dan suasana kunjungan wisatawan dalam pembelian produk, dan 5) Human Interest yang berisi profil masyarakat sebagai perajin rotan dalam aktifitasnya; profil para pengelola desa wisata dalam aktifitasnya; profil para pemangku kepentingan dalam aktifitasnya di 
Desa Trangsan; dan profil wisatawan yang pernah berkunjung menikmati produk wisata edukasi di Desa Trangsan.

\section{Konsep 5W+1H}

Sebagai media komunikasi visual, coffee table book juga disusun dengan mengacu pada konsep $5 \mathrm{~W}+1 \mathrm{H}$. Konsep ini diterapkan untuk mengemas informasi agar mudah dipahami oleh audiens (Fachruddin, 2019). Revolusi jurnalisme berkaitan dengan bagaimana menyampaikan ide dalam wujud tulisan. Konsep $5 \mathrm{~W}+1 \mathrm{H}$ (what, when, where, why, who, dan how) mengacu pada fakta-fakta di lapangan. Roy Peter mengembangkan konsep klasik tersebut menjadi tulisan model menjadi: What, potensi Desa Trangsan apa saja yang akan disajikan dalam bentuk narasi maupun karya fotografi dalam coffee table book tersebut. Who, siapa yang akan menjadi subjek dan obyek dalam coffee table book tersebut dan masing-masing akan menyampaikan pesan apa kepada target audiens. Why, mengapa coffee table book tersebut disusun dan mengapa pesan di dalamnya penting untuk diketahui target audiens. When, kapan kejadian tersebut berlangsung dan bagaimana pengolahan informasinya sebagai materi di coffee table book tersebut. Where, di mana saja lokasi ditentukan untuk disajikan sebagai materi dalam coffee table book tersebut. How, bagaimana pesan diolah menjadi bahasa verbal dan visual dan bagaimana teknik serta proses perancangan coffee table book tersebut.

Coffee table book Desa Trangsan ini menyasar pada target audiens secara geografis pada lingkup nasional, karena teks buku dalam bahasa Indonesia. Secara demografis mencakup usia minimal 20 tahun, berjenis kelamin laki-laki dan perempuan dengan status sosial pejabat pemerintah, pengusaha, mahasiswa, dan karyawan. Secara psikografis dengan profil pembaca yang tertarik pada karya-karya kerajinan rotan, gemar mengunjungi desa wisata, gemar mengunjungi wisata experience, dan lain sebagainya.

\section{Table of Content Coffee Table Book "Trangsan. Desa Wisata Rotan yang Mendunia"}

Setelah melaksanakan FGD, maka disepakati mengenai isi apa saja yang akan 
menjadi konten. Coffee table book dengan judul "Trangsan. Desa Wisata Rotan yang Mendunia" ini disusun menjadi beberapa bagian, seperti diuraikan dalam Tabel 1. Sedangkan tampilan isi coffee table book ini ditunjukkan dalam Gambar 2.

Tabel 1. Pembagian BAB dalam Coffee Table Book “Trangsan. Desa Wisata Rotan yang Mendunia"

BAB

Bab 1.

Rotan dan Lingkungan, yang memaparkan konsep rotan sebagai produk ramah

lingkungan dan memaparkan tentang kegiatan pelestarian rotan yang pernah dilakukan.

Bab 2. Sejarah Desa Trangsan. Memaparkan sejarah singkat Desa Trangsan sebagai Desa Wisata Industri Kerajinan Rotan; sejarah dan konsep penetapan Desa Trangsan sebagai Desa Wisata Industri Kerajinan Rotan.

Bab 3. Trangsan, Desa Industri Kerajinan Rotan. Menampilkan bangunan-bangunan rumah penduduk sebagai lokasi produksi; armada dan suasana aktivitas bongkar muat bahan baku maupun produk kerajinan rotan; beberapa rumah penduduk yang digunakan sebagai lapak penjualan dan aktivitas transaksinya, dan sebagainya.

Bab 4. Rotan sebagai Sumber Penghidupan. Menampilkan foto rotan mentah, rotan yang telah diolah dan proses pengolahan rotan sebagai bahan baku; proses pengolahan rotan sebagai produk kerajinan; peralatan pengolahan bahan baku yang digunakan perajin; profil para perajin dengan aktifitasnya; suasana kerja dan suasana tempat bekerja; suasana kunjungan investor, buyer, dan lain-lain di lokasi produksi atau sejenisnya.

Bab 5. Kerajinan Rotan Desa Trangsan yang Mendunia. Menampilkan dokumentasi suasana stand dan kegiatan keikutsertaan dalam pameran nasional/internasional; dokumentasi karya-karya masterpiece kerajinan rotan dari berbagai kategori yang luar biasa: best seller, tematik, favorit, dan sebagainya.

Bab 6. Desa Wisata Rotan Trangsan. Menampilkan dokumentasi event Grebeg Penjalin; dokumentasi aktifitas kunjungan wisatawan. 

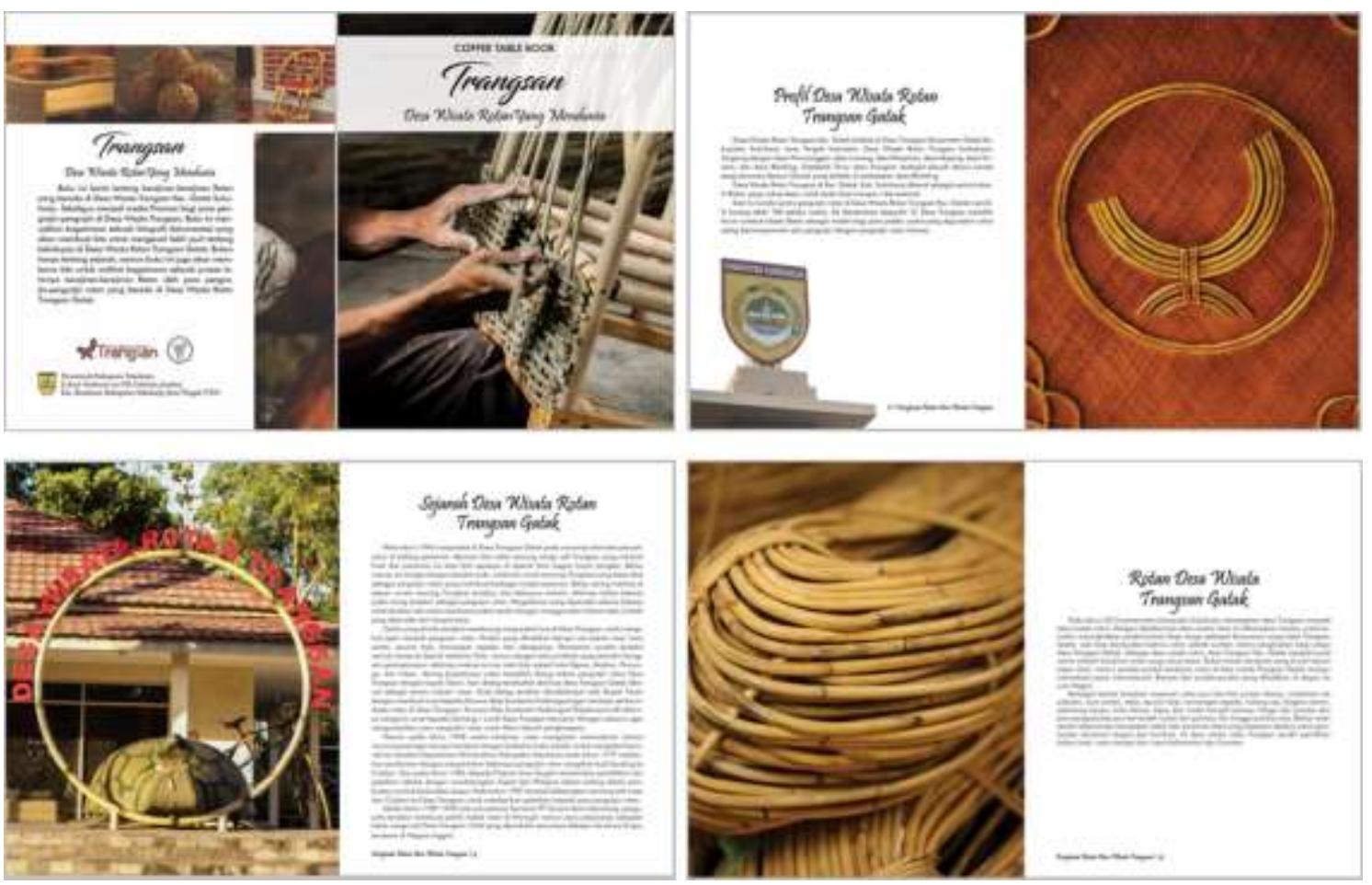

Gambar 2. Tampilan beberapa halaman Coffee Table Book Desa Trangsan

\section{Data Pendukung Potensi Desa Wisata Trangsan yang Dituangkan dalam Coffee Table Book}

Data pendukung yang menjadi pendukung penciptaan coffee table book diperoleh melalui kajian pustaka, observasi berpartisipasi pasif, dan focus group discussion. Dari pengumpulan data menggunakan ketiga metode tersebut diperoleh data yang menyatakan bahwa (1) kerajinan rotan Desa Trangsan mulai bernilai ekspor sejak 1986. Ini dicapai dari aktivitas masyarakat ketika pemerintah memberikan pelatihan kepada perajin; (2) sebelum ada pelatihan, masyarakat Trangsang mayoritas berprofesi sebagai petani; (3) pada 1987, para perajin hasil pelatihan mulai dapat melayani pemesanan produk rotan. Pemesan berasal dari dalam dan luar negeri; (4) sejak berkembangnya produk ini, ekspor kerajinan rotan Desa Trangsan mengalami dinamika kemajuan yang baik; (5) puncak ekspor kerajinan rotan Desa Trangsan terjadi pada periode 1990-an hingga 2005; (6) selain kemajuan, penurunan secara signifikan juga terjadi mulai tahun 
2005 hingga 2009 yang dipengaruhi oleh krisis bahan baku rotan dan krisis ekonomi global yang melanda Amerika Serikat mulai 2008. Keberadaan industri pengolahan rotan komoditas ekspor telah mempengaruhi kehidupan sosial ekonomi masyarakat Desa Trangsan.

Industri pengolahan rotan telah mengakibatkan terjadinya perubahan sosial masyarakat Desa Trangsan. Masyarakat yang awalnya bersifat agraris berubah menjadi masyarakat industri. Industri tersebut juga mengakibatkan terbentuknya stratifikasi sosial yang terbagi menjadi pengusaha rotan dan perajin rotan. Dilihat dari segi jumlah pekerja dan produksinya dibagi menjadi pengusaha skala besar, menengah, kecil, dan rumah tangga. Selain itu, etos kerja masyarakat juga semakin tinggi. Industri tersebut juga mempengaruhi pembangunan masyarakat Desa Trangsan, seperti pemberian izin jalan desa dilalui truk kontainer, pembangunan jalan, pembangunan klinik, Puskesmas, dan pembangunan potensi pariwisata

Jika ditinjau dari data pendukung perlunya dikembangkan penciptaan coffee table book sebagai salah satu upaya membangkitkan potensi Desa Wisata Trangsan, dapat pula dikatakan bahwa potensi desa ini masih dapat dikembangkan lebih intensif seperti diterangkan oleh Mahanani (2018). Dalam tulisannya mengemukakan analisis strategi pemasaran Desa Trangsan sebagai Desa Wisata rotan. Strategi pemasaran di desa ini memperluas inovasi para perajin rotan Trangsan. Penjualan produk yang dihasilkan tidak hanya manual artinya dari mulut ke mulut saja melainkan juga sudah merambah online atau internet. Selain itu dari FGD bersama perangkat desa dan perajin, dinyatakan bahwa sebenarnya diperlukan alat pemasaran yang lebih representatif jika konsumen datang ke desa ini, sehingga coffee table book dapat diciptakan menjadi sebuah solusi. Fasilitas tersebut juga membantu dalam meningkatkan penjualan tidak hanya lokal Sukoharjo namun juga secara nasional merambah ke berbagai daerah. Hal yang senada dikemukakan dalam riset Mursito dan Harini (2017) mengenai pemberdayaan perajin. Pemberdayaan perajin rotan di Desa Trangsan diwujudkan melalui koperasi. 
Sebelum dikembangkan penciptaan coffee table book ini, perancangan coffee table book sudah dihasilkan oleh mahasiswa dari berbagai perguruan tinggi sebagai karya skripsi atau thesisnya. Andhika (2015), Meidiyani (2015), Kusuma (2016), Vincentius, Karnadi, dan Renaningtyas (2016), serta Gumilang dan Setiawan (2018) dalam penelitian-penelitian tersebut semuanya menghasilkan coffee table book untuk berbagai produk desa wisata. Namun demikian belum ada dijumpai karya coffee table book yang dihasilkan membahas tentang kerajinan rotan atau Desa Trangsan. Sementara itu, kajian-kajian yang sudah ada dan merupakan hasil riset berfokus pada strategi pengembangan desa wisata, strategi pengelolaan destinasi wisata, pemberdayaan masyarakat menjadi kajian-kajian yang mendasari penelitian dan penyusunan coffee table book untuk Desa Trangsan ini.

\section{KESIMPULAN}

Konsep coffee table book beserta kekuatan fotografi diciptakan sebagai media komunikasi kegiatan pemasaran produk rotan Desa Trangsan sebagai Desa Wisata mendapat respon yang baik oleh masyarakat yang bersangkutan. Hal ini disebabkan coffee table book Desa Wisata Industri Kerajinan Rotan Trangsan disajikan dalam format E-Book. Format ini akan mampu dinikmati dengan baik bagi konsumen, karena menyajikan kualitas gambar yang prima, narasi dan caption secara terstruktur, sumber informasi yang jelas, dan sebagainya, sehingga diharapkan efektivitas komunikasi akan lebih terjamin keberlangsungannya. Selain sebagai cinderamata, coffee table book akan lebih bermanfaat apabila disajikan sebagai media komunikasi digital yang bisa diakses oleh smartphone atau gadget lain agar penyebaran informasi tentang destinasi wisata Trangsan ini bisa terpublikasikan dengan baik secara luas dan tanpa batas.

Data pendukung untuk memaparkan potensi sumber daya wisata Desa Trangsan dalam bentuk coffee table book sebagai media komunikasi kegiatan pemasaran produk rotan Desa Trangsan sebagai Desa Wisata diperoleh dengan 
melakukan studi dokumen terhadap hasil-hasil riset terdahulu, observasi lokasi, dan dan focus group discussion. Ini dilakukan karena keterbatasan pengetahuan dan keterampilan masyarakat. Keterbatasan pengetahuan dan keterampilan masyarakat atas sistem pengumpulan data berupa foto dokumentasi yang mereka miliki menjadi kendala yang cukup berarti dalam proses penyusunan coffee table book ini. Masyarakat tidak terbiasa menyimpan dokumentasi kegiatan mereka dalam satu sistem penyimpanan yang terpusat atau database, sehingga pengumpulan data berupa foto dokumentasi kegiatan membutuhkan proses yang cukup panjang, karena harus melibatkan banyak orang dengan implementasi teknik pendekatan yang bervariasi pada tiap orang. Akan tetapi, kendala tersebut bisa diatasi atas kerjasama dan komunikasi yang baik dengan warga.

Coffee table book Desa Wisata Industri Kerajinan Rotan Trangsan dalam format E-Book ini berfungsi sebagai media komunikasi visual, sebagai ikon pencitraan (branding), dan sebagai elemen penting dalam program pemasaran Desa Trangsan sebagai Desa Wisata Industri Kerajinan Rotan, coffee table book ini menjadi media yang strategis. Peran pentingnya perlu didukung oleh program-program pemasaran lainnya sebagaimana implementasi konsep IMC dalam pemasaran suatu destinasi wisata. Hal itu menjadi peluang program-program pengembangan Desa Wisata Industri Kerajinan Rotan Trangsan selanjutnya.

Dari simpulan tersebut di atas disampaikan saran kepada peneliti-peneliti selanjutnya yang menciptakan dan mengembangkan coffee table book dimohon dapat merujuk hasil riset ini sebagai referensi untuk mengembangkan kemajuan pemasaran produk lokal menjadi produk internasional. Saran selanjutnya ditujukan kepada pemangku dan aparat penggerak perekonomian bagi masyarakat industri kreatif agar memperhatikan pengembangan alat komunikasi promosi berbentuk coffee table book tidak hanya berbentuk cetak, namun juga berbentuk digital. Saran berikutnya ditujukan kepada pengembang desain coffee table book untuk berbagai industri kreatif di seluruh tanah air dimohon untuk memperhatikan kualitas fotografi 
yang prima untuk memperkuat terciptanya coffee table book yang efektif sebagai alat komunikasi kegiatan pemasaran produk industri kreatif.

\section{UCAPAN TERIMA KASIH}

Ucapan terimakasih kami sampaikan kepada LPPM Universitas Sebelas Maret yang telah mendanai kegiatan melalui Hibah Research Group Penelitian Tahun 2020. Kepada Perangkat Desa, Forum Rembug Klaster Rotan Desa Trangsan, KSU Manunggal Jaya, Pokdarwis, Bumdes, dan masyarakat Desa Trangsan, Gatak, Sukoharjo, atas kerjasama dalam berkolaborasi dan bersinergi dalam program penelitian ini.

\section{Daftar Pustaka}

Apriyanto, A. (2016) Dinamika Ekspor Kerajinan Rotan Desa Trangsan Kecamatan Gatak Kabupaten Sukoharjo Tahun 1986-2009. Skripsi. UNS-FIB Jur.IImu Sejarah. https://digilib.uns.ac.id/

Arida, I. N. S. dan Pujani. L.P. K. (2017) 'Kajian Penyusunan Kriteria-Kriteria Desa Wisata Sebagai Instrumen Dasar Pengembangan Desa Wisata', Jurnal Analisis Pariwisata. $17(I), 1-9$.

Fachruddin, A. (2019) Journalism today. Jakarta: Kencana Publishing. ISBN: 978-602422-919-1

Gumilang, P. dan Setiawan, H. (2018) Perancangan Coffee-Table Book Tentang Objek Wisata Di Wilayah Garut Selatan. Serat Rupa Journal of Design, 1(3), 431. https://doi.org/10.28932/srjd.v1i3.463

Handojo, C. V., Karnadi, H., dan Renaningtyas, L. (2017) Perancangan Buku Coffee Table Book Photography Mainan Tempo Dulu Era 70-An. Jurnal DKV Adiwarna. 1 (8), http://publication.petra.ac.id/index.php/dkv/article/view/4469. Inskeep, E. (1991) Tourism Planning: An Integrated and Sustainable Development Approach. New 
York: Van Nostrand. Reinhold

Juska, J. M. (2017) Integrated Marketing Communication: Advertising and Promotion in a Digital World. $1^{\text {st }}$ Edition. Oxfordshire: Routledge Publishing.

Kusuma, V. S. (2016) Perancangan Coffee Table Book Bilingual Coffee Table Book "Solo International Performing Arts Journey" Dan Media Pendukungnya. Universitas Sebelas Maret https://digilib.uns.ac.id/

Mahanani, N. U. (2018) Strategi Pemasaran Desa Wisata Rotan Trangsan Kecamatan Gatak Kabupaten Sukoharjo. Thesis. Universitas Sebelas Maret. https://eprints.uns.ac.id/39476/

Marsono (2019) Agro dan Desa Wisata: Profil Desa Wisata di Daerah Istimewa Yogyakarta dan Jawa Tengah. Yogyakarta: Gadjah Mada University Press.

Meidiyani, T. (2015) Perancangan Coffee Table Book Melalui Desain Komunikasi Visual sebagai Media Promosi Pariwisata Magelang. Tugas Akhir. Universitas Sebelas Maret. https://digilib.uns.ac.id/

Mursito, B. dan Harini. (2017) Pemberdayaan Pengrajin Melalui Koperasi Di Desa Trangsan. In Seminar Nasional dan Call for Papers UNIBA, Universitas Islam Batik Surakarta.

Shinta, A. (2011) Manajemen Pemasaran (Vol. 1). Surabaya: UB Press. ISBN: 978-6028960-28-1

Subandi. (2011) Deskripsi Kualitatif Sebagai Satu Metode Dalam Penelitian Pertunjukan, Harmonia: Journal of Arts Research and Education, 11(2), 173-179 Sumarno, Pramutomo, R. M., Cahyana, A. dan Dasmadi (2019) Grebeg Penjalin, Transformasi Dari Petani-Perajin Bambu, Sentra Industri Mebel Rotan, Ke Wisata Edukasi Industri Mebel Rotan. Prosiding Seminar Nasional Pelaksanaan Pengabdian Masyarakat (SNPM). Universitas Ciputra. Surabaya. 6 September.

Sunarta, N. dan Arida N.S. (2017) Pariwisata Berkelanjutan. Bali: Cakra Press.

Tracy, S. J. (2013) Qualitative Research Methods Collecting Evidence, Crafting Analysis, Communicating Impact. Oxford: Wiley-Blackwell. 
Tri D., Y.A. (2020) Perancangan Coffee Table Book Sebagai Media Promosi Kerajinan Rotan Desa Wisata Trangsan Gatak Sukoharjo. Tugas Akhir. Prodi Diploma III Desain Komunikasi Visual. Sekolah Vokasi. Surakarta: Universitas Sebelas Maret. https://digilib.uns.ac.id/dokumen/69462/Perancangan-Coffee-Table-BookSebagai-Media-Promosi-Kerajinan-Rotan-Desa-Wisata-Trangsan-Gatak-Sukoharjo

Vincentius, D. A., Karnadi, H., dan Renaningtyas. L., (2016) Perancangan Coffee Table Book Semangat Hidup Pedagang Tradisional. Jurnal DKV Adiwarna, 1(8), http://publication.petra.ac.id/index.php/dkv/article/view/4465

Wb., I. (2007). Anatomi Buku (Mutia Praheswari \& Agustin Rozalena (eds.)). Bandung: Kolbu. 